Research article

\title{
Community Perception and Participation of the Forestry Partnership Scheme on PT. Restorasi Ekosistem Indonesia Working Area in Jambi Province
}

\author{
Erwin Herwindo ${ }^{{ }^{*}}$, Rosyani ${ }^{1}$, Eva Achmad ${ }^{1}$ \\ ${ }^{1}$ Environmental Science Master Program, Faculty of Postgraduate, Universitas Jambi, Jl. H. A. Manaf \\ Telanaipura-Jambi 36122 \\ *Corresponding author, email: e.herwindo@gmail \\ (c) (1) (2)
}

\begin{abstract}
Granting legal access to PT. REKI in ex. PT. The Asialog concession area in 2010 was marked by resistance accompanied by violence and claims by community groups (claimer). Conflict resolution with the Forestry Partnership approach resulted Forestry Partnership Recognition and Protection (Kulin KK) agreements for 79 heads of households who were members of 4 (four) groups. The question of this research is how the perceptions and participation of Kulin KK holders and the relationship between the two variables. The objectives of the study are to analyse the perceptions and participation and the relationship of its variables. This research is descriptive with a quantitative approach. The sampling technique used the census method with many respondents and 75 holders of legal access to Kulin KK. Perception and participation analysis and categorisation use 3 (three) point Likert scale and the score interval equation. The analysis of the relationship between perception and participation variables uses the Spearman correlation analysis. The results showed that the public perception of the provisions of the Forestry Partnership scheme was in the high category of $96 \%$ and $4 \%$ in the medium category, while the level of community participation was in the high category of $36 \%, 24 \%$ medium and $40 \%$ low. Perception and participation are negatively related.
\end{abstract}

Keywords: perception, participation, Forestry Partnership, Kulin KK

\section{Introduction}

Deforestation and forest area degradation in Indonesia have negative implications for the stability of the ecosystem as a buffer for human life and welfare systems. Forest Watch Indonesia (2018) reported the deforestation rate in 2000 was 2 million hectares $(\mathrm{Ha}) / y e a r(\mathrm{yr})$, in the $2000-2009$ period 1.5 million Ha/yr, 1.1 million $\mathrm{Ha} / \mathrm{yr}$ in 2009-2013 and for the period 2013-2017 of 1.47 million Ha/year. National forest cover has decreased from 106.4 million hectares in 2000 to the remaining 82.8 million hectares in 2017 , or about $43 \%$ of Indonesia's land area. Around 30 million hectares of production forest are not managed intensively in open-access conditions. The government responded to this situation by issuing discretion through the Minister of Forestry Regulation Number SK.159/Menhut-II/2004 concerning Ecosystem Restoration in production forest areas (Kartodihardjo, 2019).

For the first time in 2007, the government granted a Business Permit for the Utilisation of Ecosystem Restoration Timber Forest Products (IUPHHK-RE) to PT. Restorasi Ecosystem Indonesia (PT. REKI) covering an area of \pm 52,170 Ha whose work area is located in Musi Banyuasin Regency, South Sumatra Province. This was followed by granting a second IUPHHK-RE to the same company in an area 
of $\pm 46,385$ Ha through the Decree of the Minister of Forestry Number SK.327/Menhut-II/2010 dated May 25, 2010. In the decree, PT. REKI is burdened with the obligation to carry out maintenance, protection and restoration activities of forest ecosystems to restore biological and non-biological elements in an area to their original species so that biological balance and ecosystems are achieved.

PT. REKI in Jambi Province is administratively included in the Kunangan Jaya Hamlet, Bungku Village, Batang Hari Regency. This area is included in the degraded production natural forest category after being managed by Forest Concession Rights PT. Asia Log and part of PT. Inhutani. Pujayanti (2014) and Qodriyatun (2016) reveal that the area has been neglected and not managed intensively since 2001. This condition creates opportunity sets for people, either because of economic pressure or those who are economically strong (Harun and Dwiprabowo, 2014) and encourage many parties to use the land (Gamin, 2014) by carrying out illegal logging, buying and selling land, clearing land to develop plantation areas (oil palm, rubber) and planting secondary crops. PT. REKI (2020) shows that in the period 2009-2018, there has been an increase in dryland agriculture by $\pm 7,467 \mathrm{Ha}$ or $15.48 \%$ and open land covering an area of $\pm 5,754 \mathrm{Ha}$ or $12.03 \%$ of the work area of PT. REKI. Meanwhile, the claimed work area until 2019 reached $\pm 22,270$ Ha or $48 \%$ of the work area of PT. REKI. The community groups involved in land claims were 17 groups consisting of 3,109 heads of families (KK) and 12,290 people.

Settlement of tenure conflicts in the work area of PT. REKI using a forestry partnership approach (Weni et al., 2020) has resulted in legal access to the Recognition and Protection of Forestry Partnerships (Kulin KK) for 79 families or $2.8 \%$ of the total number of 2,777 claimant families with a partnership area of $\pm 1,189.31$ Ha or $5.3 \%$ of the entire claim area of $\pm 22,270$ Ha (PT. REKI, 2020). Positive community perception of forest management is an essential factor in partnership management (Narsuka et al., 2009). A person's perception of activity can influence him to engage in that activity. The program's success involving members of the Forest Farmers Group (KTH) is strongly influenced by their perception and participation in the program in question (Suhesti and Hadinoto, 2019). Therefore, the perception and participation of the community level towards the Forestry Partnership scheme can be an indicator of optimising conflict resolution in the PT. REKI. If the Forestry Partnership program is successful, other communities without being invited will offer to join (Rukminda, 2020). This study analyses the perception and level of community participation and the relationship between the two variables. This research is expected to contribute practical thoughts to the Forestry Partnership actors

\section{Research Methods}

\subsection{Materials}

This research includes descriptive research with a quantitative approach. According to Sugiyono (2019), this method is called the quantitative method because the research data is in numbers, and the analysis uses statistics. This research was conducted from September 2020 to October 2020 in the work area of PT. REKI administratively belongs to the Bungku Village area, Bajubang District, Batang Hari Regency. Research respondents are holders of legal access to Kulin KK, which still exist as many as $75 \mathrm{KK}$. The sampling technique used was the census method. Sugiyono (2018) stated that research conducted on populations under 100 should be carried out using a census. The primary data of the study was obtained from the results of questionnaires and interviews with respondents. In contrast, the secondary data was obtained through searching the archives of documents related to the substance and object of the research.

This study uses 2 (two) variables, namely the respondent's perception of the provisions of the Forestry Partnership scheme with 5 (five) leading indicators, namely 1) understanding of the Forestry Partnership scheme, 2) the rights of the Kulin KK holder, 3) the obligations of the Kulin KK holder, 4 ) benefits obtained by Kulin KK holders, 5) mentoring and coaching for Kulin KK holders and variable level of respondent participation in Forestry Partnership activities with 4 (four) leading indicators, namely 1) planning. 2) implementation, 3) control, and 4) utilisation of results. 
To assess the level of perception and level of participation of respondents used a 3 (three) Likert scale point with alternative answers (1) indicating disagree, (2) disagree, and (3) agree with the provision that the higher the score, the respondents' perceptions and participation are also getting higher. For the questionnaire data to be credible, validity testing was carried out using the item validity approach with the corrected item-total correlation method and reliability using the Cronbach's Alpha calculation method (Priyatno, 2016). Furthermore, for valid and reliable data, the score of each variable and the total score of all variables are calculated. The high-low category of the perception variable and the level of respondents' participation refers to the class division of the score interval obtained from the equation:

Score Interval : $\quad \frac{\text { the difference between the highest total score and the lowest total score }}{\text { number of classes }}$

To analyse the relationship between perceptions and the level of respondent participation, the Spearman correlation analysis approach (Sugiyono, 2019) is used with the formula:

$$
r_{s}=1-\frac{6 \sum_{i=1}^{n} d_{i}^{2}}{n\left(n^{2}-1\right)}
$$

Information :

$r_{s} \quad:$ Spearman correlation coefficient

$6 \quad$ : constant

$\sum d_{i}^{2} \quad$ : the square of the difference between the ranks of two variables

$\mathrm{n} \quad$ : Number of observations (sample)

To find out the significance of the Spearman correlation coefficient, a two-sided significance test was carried out using the $\mathrm{z}$ formula (Sugiyono, 2019):

$$
z=r_{s} \sqrt{n-1}
$$

Information :

$\mathrm{Z} \quad$ : Spearman correlation coefficient significance test value

The proposed hypothesis is:

Ho : there is no relationship between $\mathrm{X}$ and $\mathrm{Y}$

$\mathrm{Ha}$ : there is a congruent/incompatible relationship between $\mathrm{X}$ and $\mathrm{Y}$

Decision making criteria:

1. If $\mathrm{z}<-$ ztable and $\mathrm{z}>\mathrm{z}$ table at $\alpha=0.01$ and $\alpha=0.05$, then reject Ho

2. If $\mathrm{z}>-\mathrm{z}$ table and $\mathrm{z}<\mathrm{z}$ table at $\alpha=0.01$ and $\alpha=0.05$, then accept Ho

\section{Result and Discussion}

\subsection{Respondent's Perception}

The majority of respondents' perceptions of the provisions of the Forestry Partnership scheme are in the high category with a percentage of $96 \%$, the medium category is $4 \%$, and none of the respondents has a low level of perception. The high level of respondent perception is thought to have occurred because the Forestry Partnership socialisation process to respondents was carried out intensively, especially influential actors in the internal group by relevant government officials and PT. REKI since the enactment of Permenhut Number P.39/Menhut-II/2013 concerning Empowerment of Local Communities through Forestry Partnerships until the passage of the provisions of PermenLHK Number P.83/MenLHK/Setjen/Kum.1/2016 concerning Social Forestry. 
Table 1. Respondents' perceptions of the provisions of the Forestry Partnership scheme

\begin{tabular}{|c|c|c|c|c|c|c|c|c|c|c|}
\hline \multirow{3}{*}{ Categories } & \multicolumn{8}{|c|}{ Group Name } & \multirow{2}{*}{\multicolumn{2}{|c|}{ Total }} \\
\hline & \multicolumn{2}{|c|}{ Gelinding } & \multicolumn{2}{|c|}{ Tanding } & \multicolumn{2}{|c|}{ KTH LJ } & \multicolumn{2}{|c|}{ KTH HAL } & & \\
\hline & $\mathrm{N}$ & $\%$ & $\mathrm{~N}$ & $\%$ & $\mathrm{~N}$ & $\%$ & $\mathrm{~N}$ & $\%$ & $\mathrm{~N}$ & $\%$ \\
\hline High & 5 & 62,5 & 16 & 100 & 22 & 100 & 29 & 100 & 72 & 96,0 \\
\hline Medium & 3 & 37,5 & o & o & o & 0,0 & o & 0,0 & 3 & 4,0 \\
\hline Low & o & o & o & o & o & 0,0 & o & 0,0 & o & 0,0 \\
\hline
\end{tabular}

PT. REKI as a legitimate production forest area manager is proactive in solving encroachment and other illegal activities by inviting community groups to understand the benefits of maintaining and returning land clearing to forest/forest restoration (PT. REKI, 2020). These efforts have fostered understanding and mutual trust so that the parties agreed to cooperate in partnership as an instrument of conflict resolution. This is in line with one of the principles of the Forestry Partnership, which is built on mutual trust between the parties (Wiati et al., 2019).

Table 2. Categories of respondents' perceptions based on indicators

\begin{tabular}{|c|c|c|c|c|c|c|c|c|c|c|}
\hline \multirow[t]{2}{*}{ Categories } & \multicolumn{2}{|c|}{ Comprehension } & \multicolumn{2}{|c|}{ Right } & \multicolumn{2}{|c|}{ Obligation } & \multicolumn{2}{|c|}{ Profit } & \multicolumn{2}{|c|}{$\begin{array}{c}\text { Mentoring/ } \\
\text { Coaching }\end{array}$} \\
\hline & $\mathrm{N}$ & $\%$ & $\mathrm{~N}$ & $\%$ & $\mathrm{~N}$ & $\%$ & $\mathrm{~N}$ & $\%$ & $\mathrm{~N}$ & $\%$ \\
\hline High & 71 & 94,7 & 72 & 96,0 & 69 & 92,0 & 57 & 76,0 & 54 & 72,0 \\
\hline Medium & 3 & 4,0 & 2 & 2,7 & 5 & 6,7 & 18 & 24,0 & 21 & 28,0 \\
\hline Low & 1 & 1,3 & 1 & 1,3 & 1 & 1,3 & $\mathrm{o}$ & 0,0 & $\mathrm{o}$ & 0,0 \\
\hline
\end{tabular}

Based on Table 2, respondents' assessment of the indicators of perception of understanding shows that the majority have perceptions belonging to the high category with a percentage of $94.7 \%$. Respondents generally agree with the knowledge that local communities are the main actors of the Forestry Partnership in state forest areas that have been granted a PT. REKI. Likewise, with the provision that the land area of the partnership area is limited to a maximum of 5 ha. This is reinforced by the primary research data, which shows that most respondents $(89.3 \%)$ work in the partnership area between $0.5-5 \mathrm{Ha}$. Respondents also agreed with the provision that the partnership area is a state forest that cannot be given ownership rights, cannot be changed its function, traded, pledged, expanded without a permit, and plant oil palm plantations.

Respondents' perceptions of the rights of the majority of Kulin KK holders belong to the high category with a percentage of $96 \%$ (Table 2). Respondents agree that holders of legal access to Kulin KK have the right to conduct business activities and are entitled to the results in the partnership area; get protection from disturbance, destruction and or environmental pollution or unilateral takeover by other parties in the partnership area; receive assistance starting from the use of partnership area activities, counselling, use of technology, access to financing to marketing which is a form of strengthening entrepreneurship. The fulfilment of these rights can run more optimally if the group of Kulin KK holders is designated as a Social Forestry Business Group (KUPS) by the authorities as stipulated in the Perdirjen Social Forestry and Environmental Partnership (PSKL) Number P.2/PSKL/SET/KUM. I/5/2018 concerning Guidelines for Social Forestry Business Development. This determination paved the way for respondents to obtain business development facilitation from the government. This will foster a sense of calm and comfort, as Rukminda (2020) stated that recognition and protection affect the tranquillity, comfort, and security of the community in managing forests.

Respondents' perception of obligations is classified as the high category with a percentage of 92\%. The majority of respondents agreed with the obligation to deposit Non-Tax State Revenue (PNBP) on forest products in the partnership area, the payment of which was facilitated by PT. REKI; the 
obligation to comply with each item of the Cooperation Agreement (NKK); protect the partnership area from potential fires, acts of destruction, arson, theft, poaching and poisoning of animals inside and outside the partnership area/assets of PT. REKI; to mark the boundaries of the partnership area; prepare a management plan; carry out planting and maintenance in the partnership area; carry out the administration of non-timber forest products for commodities produced from the partnership area. Wiati et al. (2020) revealed that palm oil and rubber commodities had been the mainstay of the harvest of KTH members so that their use must be following the points of these obligations.

Respondents' perceptions of the benefits of Kulin KK are in the high category with a percentage of $76 \%$. The majority of respondents in all groups of Kulin KK holders agree that there are benefits in the form of being allowed to use oil palm plantations that have been planted in the partnership area for 12 years from the time of planting and between oil palm trees planted with woody trees at least 100 trees per ha; agreement on profit sharing originating from timber forest staple crops, NTFPs and environmental service management businesses; profit-sharing understanding of $85 \%$ for respondents and $15 \%$ for PT. REKI, as well as improvements to infrastructure and public/social facilities that are carried out collaboratively. The profit-sharing portion of the permit holder of $15 \%$ is used to pay for PNBP and infrastructure improvements and public facilities as well as social facilities. Thus, the Forestry Partnership scheme provides financial and physical benefits to community groups holding Kulin KK on the one hand and increases the stability of forest management by permit holders on the other. This aligns with Yuwono's (2006) research, which states that community forest farmers understand the partnership agreement between the farmers and PT. Xylo Indah Pratama in Musi Rawas Regency benefits both parties.

Respondents' perceptions of assistance and guidance for Kulin KK are classified as the high category with a percentage of $72 \%$. Respondents generally agree with the technical assistance or guidance from the Government and the Working Group for the Acceleration of Social Forestry (Pokja PPS) because these parties will assist community groups in increasing the capacity of partnership area management, institutional management and business management. However, some respondents who gave an assessment that they disagreed, reasoned that the actual conditions on the ground showed that the government and the Pokja PPS had not yet felt the role of mentoring and its couching. This can hamper the productivity of the Kulin KK community group in the partnership area. Utami and Ratnaningsih (2018) revealed that the lack of counselling to farmer groups at BPKH Rinjani Barat Pelangan Tastura had become one of the inhibiting factors for forestry partnerships.

\subsection{Respondent Participation Rate}

Respondents' participation in Forestry Partnership activities is divided into planning activities, implementing activities, controlling, and utilising results. The level of participation of respondents in Forestry Partnership activities as a whole is presented in Table 3. Based on the table, as many as $40 \%$ of respondents have a participation rate belonging to the low category, respondents with a high level of participation in $36 \%$ and the remaining $24 \%$ belonging to the medium category. This illustrates that most of the respondents have not been much involved in the activities of the Forestry Partnership. The low level of respondent participation, especially KTH HAL is thought to have occurred due to several factors, namely: (1) preferences that are not in line with the Forestry Partnership policy, (2) the presence of high-security risk areas, (3) the duration of the management plan, (4) guarantees market and market access, (5) injustice in the imposition of obligations on partner and non-partner communities, and (6) intensity of assistance.

Massiri et al. (2016) stated that preferences would determine community behaviour towards forests. Rahmani's research (2020: 44-45) reveals the preferences of the working community in the work area of PT. REKI wants forest land management to generate money every month, thus encouraging people to choose oil palm plantations. Meanwhile, the continuation of oil palm plantations in the partnership area is only allowed for 12 years from the planting period. Among the oil palm plantations, 
at least 100 trees/ha are planted with woody trees. The dominance of migrants or migrants who have not partnered in Dusun Kunangan Jaya II as the basis for KTH HAL has increased security risks. PT. REKI (2020) revealed that forest area security patrols are often hampered by closing the patrol road access using wood that has been intentionally cut and felled onto the road, blocking or stopping security patrol activities with large numbers of people and conducting demonstrations that often lead to taking patrol members hostage. As a result, the implementation of the Forestry Partnership in the KTH HAL partnership area has not been effective.

Table 3. Categories of respondents' perceptions based on indicators

\begin{tabular}{|c|c|c|c|c|c|c|c|c|c|c|}
\hline \multirow{3}{*}{ Categories } & \multicolumn{8}{|c|}{ Group Name } & \multirow{2}{*}{\multicolumn{2}{|c|}{ Total }} \\
\hline & \multicolumn{2}{|c|}{ Gelinding } & \multicolumn{2}{|c|}{ Tanding } & \multicolumn{2}{|c|}{ KTH LJ } & \multicolumn{2}{|c|}{ KTH HAL } & & \\
\hline & $\mathrm{N}$ & $\%$ & $\mathrm{~N}$ & $\%$ & $\mathrm{~N}$ & $\%$ & $\mathrm{~N}$ & $\%$ & $\mathrm{~N}$ & $\%$ \\
\hline High & 3 & 37,5 & 5 & 31,2 & 19 & 86,4 & o & 0,0 & 27 & 36,0 \\
\hline Medium & 4 & 50 & 11 & 68,7 & 3 & 13,6 & $\mathrm{o}$ & 0,0 & 18 & 24,0 \\
\hline Low & 1 & 12,5 & o & o & o & 0,0 & 29 & 100 & 30 & 40,0 \\
\hline
\end{tabular}

The low community participation is also influenced by the partnership period, which has only been running for about 2 (two) years, causing several activities plans to have not been implemented. NKK between PT. REKI with KTH HAL, for example, harvesting and marketing agroforestry plants, has not been implemented because it will only be implemented in the 6th year. Market availability and market access affect the level of respondents' participation in implementing the Forestry Partnership stage. Rahmani (2020) revealed that the market and market access to market non-oil palm forest products is not as easy as marketing palm oil products. The adoption of rubber-based agroforestry programs whose market access is uncertain has led to community reluctance to develop crops other than oil palm.

According to Utami and Ratnaningsih (2018), the lack of counselling for farmer groups at BPKH Rinjani Barat Pelangan Tastura has become one of the inhibiting factors for forestry partnerships. Based on field observations, in general, community groups holding legal access to Kulin KK are not accompanied by private or government extension agencies. This is thought to affect the low level of community participation.

The dominance of respondents with low participation rates is thought to have occurred because of factors (1) the implementation of the Forestry Partnership has only been running for approximately 2 (two) years so that its implementation is limited to a few activities, (2) the implementation of the Forestry Partnership in the KTH HAL partnership area is hampered by high resistance. Non-partner community to the existence of PT. REKI, and (3) the absence of a supporting institution for community groups holding legal access to the Kulin KK that motivates and bridges the group's interests to various related parties.

Table 4. Categories of respondents' participation levels based on indicators

\begin{tabular}{lcccccccc}
\hline Categories & \multicolumn{2}{c}{ Planning } & \multicolumn{2}{c}{$\begin{array}{c}\text { Activity } \\
\text { Implementation }\end{array}$} & \multicolumn{2}{c}{ Control } & \multicolumn{2}{c}{$\begin{array}{c}\text { Outcome } \\
\text { Utilization }\end{array}$} \\
\cline { 2 - 9 } & $\mathrm{N}$ & $\%$ & $\mathrm{~N}$ & $\%$ & $\mathrm{~N}$ & $\%$ & $\mathrm{~N}$ & $\%$ \\
\hline High & 33 & 44,0 & 31 & 41,3 & 10 & 13,3 & 28 & 37,3 \\
Medium & 24 & 32,0 & 14 & 18,7 & 35 & 46,7 & 12 & 16,0 \\
Low & 18 & 24,0 & 30 & 40,0 & 30 & 40,0 & 35 & 46,7 \\
\hline
\end{tabular}

The participation rate of respondents based on participation indicators is presented in Table 4 . Based on the table, as many as $44 \%$ of respondents have a high level of participation in planning, $32 \%$ of respondents with a moderate level of participation and the remaining $24 \%$ are in a low category. This 
illustrates that some respondents, although not the majority, have been involved in many Forestry Partnership planning activities in meetings discussing plans for group formation, preparation of work plans, and marking partnership area boundaries and patrol plans. Respondents who did not attend entrust their aspirations to influential group internal actors.

Table 4 also shows that $41.3 \%$ of respondents have a high level of participation in the implementation of Forestry Partnership activities, $18.7 \%$ of respondents with a moderate level of participation and the remaining $40 \%$ are in a low category. These results illustrate the level of participation of respondents in the implementation of Forestry Partnership activities classified as high and low categories. This is because the implementation of the Forestry Partnership has only been running for about 2 (two) years, so during that time, only certain activities have been carried out, such as boundary marking, planting, maintenance, and patrolling. Meanwhile, other activities cannot be implemented, such as harvesting, forest product administration and PNBP payments.

Another indicator is the participation of respondents in controlling the Forestry Partnership. Only $13.3 \%$ of respondents have a high level of participation, $46.7 \%$ of respondents with a moderate level of participation, and $40 \%$ are in a low category. This study illustrates that respondents have not been much involved in controlling activities with the monitoring team. Control activities that are packaged in the form of focused discussions aim to gather information about the implementation of the NKK by partner community groups and PT. REKI. The respondents involved were limited to influential internal actors who had been accustomed to conveying their group's aspirations.

As for the participation of respondents in the utilisation of the results of the Forestry Partnership, $37.3 \%$ of respondents had a high level of participation, $16 \%$ of respondents with a moderate level of participation and $46.7 \%$ of respondents with an almost dominant level of participation belonged to the low category. The involvement of respondents in the utilisation of the results of the Forestry Partnership, which is classified as the high category, is the use of rubber seeds and Multi-Purpose Tree Sampling (MPTS) for agroforestry programs in the partnership area. In contrast, those belonging to the medium category are utilising public and social facilities improvements by PT. The new REKI can be realised in the 9 Batin group area. Meanwhile, respondents' involvement in the utilisation of the results of the Forestry Partnership, which is classified as the low category, is the use of facilitating market access for partnership products and the utilisation of livestock which has not been realised following the utilisation plan that has been mutually agreed.

\subsection{Relationship between Perception and Level of Participation}

The relationship between community perceptions of the provisions of the Forestry Partnership scheme and the level of participation in Forestry Partnership activities using Spearman's correlation analysis as presented in Table 5 . Based on table 5 , it is known that respondents' perceptions of the provisions of the Forestry Partnership as a whole (X) are negatively related to the level of respondents' participation in overall Partnership activities (Y). Indications of an inconsistent relationship can be seen from the percentage of respondents who perceive the provisions of the Forestry Partnership scheme in the high category of $96 \%$. In comparison, the participation rate of respondents belonging to the high category only reaches $36 \%$. Negative or inconsistent relationships are also possible, considering that the Forestry Partnership activities have only been running for about 2 (two) years since the Kulin KK approval was given. The implementation of the Forestry Partnership is only limited to a few activities. This situation only describes the current state of implementation of the Forestry Partnership activities. The level of respondent participation allows for changes to occur over time.

Although respondents' overall perception is not in line with the level of participation, not all perception variables are negatively related to the level of participation. Respondents' perceptions of understanding the Forestry Partnership scheme ( $\left.\mathrm{X}_{1}\right)$, Kulin KK rights $\left(\mathrm{X}_{2}\right)$ and Kulin KK obligations $\left(\mathrm{X}_{3}\right)$ are known to be positively related to variable $\mathrm{Y}$, while respondents' perceptions of Kulin KK benefits $\left(\mathrm{X}_{4}\right)$ and Kulin KK assistance and guidance $\left(\mathrm{X}_{5}\right)$ negatively related to variable $\mathrm{Y}$. 
Table 5. The relationship between perceptions and the level of respondents' participation

\begin{tabular}{|c|c|c|c|c|c|}
\hline \multirow[b]{2}{*}{ Variable } & \multirow{2}{*}{$\begin{array}{l}\text { Perception } \\
\text { Rate (Y) }\end{array}$} & \multicolumn{4}{|c|}{ Forestry Partnership Activities } \\
\hline & & $\begin{array}{l}\text { Planning } \\
\text { (Y1) }\end{array}$ & $\begin{array}{l}\text { Implementation } \\
\left(\mathrm{Y}_{2}\right)\end{array}$ & Control $\left(\mathrm{Y}_{3}\right)$ & $\begin{array}{c}\text { Outcome } \\
\text { Utilization } \\
\left(\mathrm{Y}_{4}\right)\end{array}$ \\
\hline Total perception (X) & $-0,354^{\text {** }}$ & $-0,211$ & $-0,371^{* *}$ & $-0,033$ & $-0,377^{* *}$ \\
\hline $\begin{array}{l}\text { Perception of } \\
\text { understanding }\left(\mathrm{X}_{1}\right)\end{array}$ & 0,224 & $0,315^{* *}$ & 0,210 & $0,400^{* *}$ & $0,241^{*}$ \\
\hline Perception of rights $\left(\mathrm{X}_{2}\right)$ & 0,101 & o,o73 & 0,146 & $0,287^{*}$ & 0,105 \\
\hline $\begin{array}{l}\text { Perception of obligation } \\
\left(\mathrm{X}_{3}\right)\end{array}$ & $0,584^{* *}$ & $0,437^{* *}$ & $0,658^{* *}$ & $0,682^{* *}$ & $0,587^{* *}$ \\
\hline Profit perception $\left(\mathrm{X}_{4}\right)$ & $-0,199$ & $-0,071$ & $-0,232^{*}$ & 0,102 & $-0,240^{*}$ \\
\hline $\begin{array}{l}\text { Perception of mentoring } \\
\text { and coaching }\left(\mathrm{X}_{5}\right)\end{array}$ & $-0,194$ & $-0,069$ & $-0,227$ & 0,102 & $-0,234^{*}$ \\
\hline
\end{tabular}

Based on the Spearman correlation value as shown in Table 5 , it is known that only the $\mathrm{X}_{1}$ and $\mathrm{X}_{3}$ variables have a positive and significant relationship at the $99 \%$ confidence level with the respondent's participation. The variable $\mathrm{X}_{1}$ has a positive and significant relationship at the $99 \%$ confidence level with the respondent's participation in planning the Forestry Partnership ( $\left.\mathrm{Y}_{1}\right)$ and the respondent's participation in controlling the Forestry Partnership $\left(\mathrm{Y}_{3}\right)$. Respondents understand that the partnership area is limited to a maximum of 5 (five) $\mathrm{Ha}$, so to ensure this, the respondent must participate in a meeting to discuss the implementation plan for marking the boundaries of the partnership area. Respondents also participated in providing data of the area and other information needed by the Monitoring Team to control the Partnership. However, the said activities could only be carried out in the Batin nine partnership area. This means that the high perception of respondents on understanding the provisions of the Forestry Partnership scheme has a significant effect on increasing respondents' participation in Forestry Partnership planning and controlling Forestry Partnership activities.

The variable $\mathrm{X}_{3}$ has a positive and significant relationship at the $99 \%$ confidence level with all variables of the level of participation, namely $\mathrm{Y}_{1}, \mathrm{Y}_{2}$ (respondent participation in the implementation of the Forestry Partnership), $\mathrm{Y}_{3}$, and $\mathrm{Y}_{4}$ (respondent participation in the utilisation of the results of the Forestry Partnership). The obligation to prepare a work plan requires respondents to discuss and agree on the Forestry Partnership's work plan with PT. REKI, although only attended by a few influential internal actors who have broader insight and knowledge. Likewise, the obligation to plant and maintain trees motivates respondents to carry out tree planting and maintenance in the partnership area. The obligation to comply with the NKK also encourages respondents to control the Forestry Partnership with the Monitoring Team to ensure that the implementation of the Forestry Partnership is following applicable regulations. The obligation to implement PUHH and PNBP payments also encourages respondents to obtain market access facilitation for products produced in the partnership area. This means that the high perception of respondents to the obligations of the Kulin KK has a significant effect on increasing respondents' participation in all stages of Forestry Partnership activities.

Increasing community participation is the keyword in overcoming the incompatible relationship between perceptions and the level of community participation holding legal access to Kulin KK. At least 3 (three) factors can strengthen the implementation of the Forestry Partnership in the PT. REKI, namely the intensity of assistance to groups of holders of legal access to Kulin KK so that all group members are motivated to carry out all stages of the Forestry Partnership, market guarantees and market access to all types of commodities that are allowed and developed in the partnership area so that holders of legal access to Kulin KK get guaranteed income. Every month, and the implementation of PP 24 of 2021 concerning Procedures for Imposing Administrative Sanctions and Procedures for PNBP Originating from Administrative Fines in the Forestry Sector with the hope that all business actors who have not obtained 
legality in the PT. REKI is subject to administrative sanctions in the form of PNBP payments as a condition of obtaining legal access to create social justice.

\section{Conclusion}

The community's perception holding Kulin KK legal access to the provisions of the Forestry Partnership scheme as a whole is in the high and medium categories with percentages of $96 \%$ and $4 \%$, respectively. The community's level of participation holding legal access to the Kulin KK in each stage of the Forestry Partnership activity is in the high category at $36 \%$, the medium category at $24 \%$, and the low category at $40 \%$. There is a relationship between the perception of the community as a whole and the level of participation as a whole, where the direction of the relationship is inconsistent or negative. Community perceptions of understanding the Forestry Partnership scheme, Kulin KK rights and Kulin KK obligations are positively related to the level of community participation. In contrast, respondents' perceptions of the benefits of Kulin KK and mentoring and guidance of Kulin KK are negatively related to the level of community participation.

\section{References}

Direktur Jenderal Perhutanan Sosial dan Kemitraan Lingkungan. 2018. Peraturan Direktur Jenderal Perhutanan Sosial dan Kemitraan Lingkungan Nomor P.2/PSKL/SET/KUM.I/5/2018 tentang Pedoman Pengembangan Usaha Perhutanan Sosial.

Forest Watch Indonesia. 2019. Lembar Fakta Angka Deforestasi Sebagai "Alarm" Memburuknya Hutan Indonesia. Bogor : Forest Watch Indonesia.

Gamin. 2014. Resolusi Konflik Dalam Pengelolaan Hutan Untuk Mendukung Implementasi REDD+. Disertasi, IPB University.

Harun, M. K. \& H. Dwiprabowo. 2014. Model Resolusi Konflik di Kesatuan Pemangkuan Hutan Produksi Model Banjar. Jurnal Penelitian Sosial dan Ekonomi Kehutanan. 11 (4), 265 - 280.

Kartodihardjo, H. 2019. Inovasi dan Penguatan Kebijakan Restorasi Ekosistem. Forest Digest Edisi 12 Juli 2019-September 2019.

Massiri, S. D., B. Nugroho, dan R. Soekmadi. (2016). Preferensi dan Motivasi Masyarakat Lokal Dalam Pemanfaatan Sumber Daya Hutan di Taman Nasional Lore Lindu, Provinsi Sulawesi Tengah. Jurnal Manusia dan Lingkungan 23 (2), 215 - 223.

Menteri Lingkungan Hidup dan Kehutanan Republik Indonesia. 2016. Peraturan Menteri Lingkungan Hidup dan Kehutanan Nomor P.83//MENLHK/SETJEN/KUM.1/10/2016 Tentang Perhutanan Sosial.

Narsuka, D. R., Sujali, dan B. Setiawan. 2009. Persepsi dan Peran Serta Masyarakat Lokal Dalam Pengelolaan TNGM. Majalah Geografi Indonesia 23 (2), 90-108.

Naskah Kesepakatan Kerjasama Kemitraan Kehutanan antara PT. Restorasi Ekosistem Indonesia dengan Kelompok Tani Hijau Alam Lestari, RT. 36, Dusun Kunangan Jaya II dengan PT. Restorasi Ekosistem Indonesia di Desa Bungku, Kecamatan Bajubang, Kabupaten Batanghari, Provinsi Jambi Nomor 056C/Reki-JBI/V/2018 dan o1/KTH-MB/V/2018.

Priyatno, D. 2016. SPSS Handbook. Yogyakarta : Mediakom.

PT. REKI. 2020. Rencana Kerja Tahunan Ijin Usaha Pemanfaatan Hasil Hutan Kayu Restorasi Ekosistem Dalam Hutan Alam Pada Hutan Produksi Periode Tahun 2020. Jambi : PT. REKI.

Pujayanti, A. 2014. LSM Internasional dan Dilema Pelestarian Di Hutan Harapan Provinsi Jambi. Jurnal Politica 5 (1), 18-36.

Qodriyatun, S. N. 2016. Konsesi Konservasi Melalui Kebijakan Restorasi Ekosistem Di Hutan Produksi. Jurnal Aspirasi 7 ( 1), 49-62.

Rahmani, T. A. 2020. Pengembangan Multiusaha Kehutanan Untuk Kesejahteraan Masyarakat dan Resolusi Konflik. Tesis, IPB University. 
Rukminda, G. M., R. Soekmadi, dan S. Adiwibowo. 2020. Perspektif masyarakat terhadap program kemitraan kehutanan sebagai solusi konflik tenurial di Kesatuan Pengelolaan Hutan Lindung Rinjani Barat. Jurnal Media Konservasi, Vol. 25 No. 1, April 2020 : 17-25.

Safitri, M. A., M. A. Muhshi, M. Muhajir, M., Shohibuddin, Y. Arizona, M. Sirait, G. Nagara, Andiko, S. Moniaga, H. Berliani, E. Widawati, S. R. Mary, G. Galudra, Suwito, A. Santosa, dan H Santoso. 2011. Menuju Kepastian dan Keadilan Tenurial. Jakarta: Epistema Institute.

Sugiyono. 2018. Statistik Nonparametris Untuk Penelitian. Bandung : Alfabeta.

Sugiyono. 2019. Statistik Untuk Penelitian. Bandung : Alfabeta.

Suhesti, E. dan Hadinoto. 2019. Persepsi dan Partisipasi Kelompok Tani Hutan Terhadap Agroforestri di Kawasan Penyangga Tahura Sutan Syarif Hasyim Riau. Jurnal Penelitian Sosial dan Ekonomi Kehutanan (16) 1, 13-23.

Utami, R. P. dan Y. Ratnaningsih. 2018. Implementasi Kemitraan Kehutanan Antara Kelompok Tani Dengan BPKH Rinjani Barat Pelangan Tastura (Studi Kasus : Gabungan Kelompok Tani Maju Lestari, Desa Pusuk Lestari, Kecamatan Batulayar, Kabupaten Lombok Barat). Jurnal Silva Samalas 1 (1), 35-44.

Weni, G. A. M., I. G. Febryano, H. Kaskoyo, dan I. S. Banuwa. 2020. Kemitraan Kehutanan Sebagai Resolusi Konflik Tenurial Di Lahan Konsesi PT. Restorasi Ekosistem Indonesia. Jurnal Belantara $3(1), 59-68$.

Wiati, C. B., S. Y. Indriyanti, K. Akhadi, A. Suprianto, dan Subarudi. 2019. Membangun Kemitraan Kehutanan Melalui Agroforestri : Sebuah Upaya Penyelesaian Konflik Di KHDTK Labanan. Bogor : IPB Press.

Yuwono, S. 2006. Persepsi dan Partisipasi Masyarakat Terhadap Pembangunan Hutan Rakyat Pola Kemitraan di Kabupaten Musi Rawas Propinsi Sumatera Selatan. Tesis, IPB University. 